\title{
Planting Density and Soybean (Glycine max L.) \\ Cultivars Effects on Yield Components in the Amazon
}

\author{
Priscila Pereira Sacramento \\ Institute of Agrarian Sciences, Federal Rural University of Amazon, Paragominas, Pará, \\ Brazil. E-mail: priscila.sacrame@gmail.com
}

Letícia Cunha da Hungria (Corresponding Author)

Soil department, Institute of Agrarian Sciences, Federal Rural University of Amazon, Belém, Pará, Brazil. E-mail: leth_hungria@hotmail.com

\section{Jamil Chaar El-Husny}

Empresa Brasileira de Pesquisa Agropecuária, Belém, Pará, Brazil.

E-mail: jamil.husny@embrapa.br

Luis de Souza Freitas

Institute of Agrarian Sciences, Federal Rural University of Amazon, Paragominas, Pará, Brazil. E-mail: luisfreitas@ufra.edu

Received: Nov. 24, 2019 Accepted: Jan. 15, $2020 \quad$ Published: Jan. 19, 2020

doi:10.5296/jas.v8i3.16277～URL: https://doi.org/10.5296/jas.v8i3.16277

\begin{abstract}
The aim of this study was to evaluate the influence of planting density and cultivar of soybean on yield components in the southeast Amazon. The experiment was carried out in an Oxisol, with a randomized block design in a $2 \times 4$ factorial scheme. The treatments were two soybean cultivars (BRS 9090 RR and BRS 8990 RR) and four planting densities (13, 15, 18 and 20 plants $\mathrm{m}^{-1}$ ), with three replications. First pod insertion height (IFP), plant height (H), number of pods per plant (NPP), grain yield (Y) and weight of 100 grains (W100) were evaluated. The insertion height of the first pod showed a tendency of increase with the increment of plants per linear meter for cultivar BRS 8990 RR, different of the behavior observed for the cultivar BRS 9090 RR, which only showed difference when the density of
\end{abstract}


300.000 plants $\mathrm{ha}^{-1}$ was tested. For plant height, among soybean cultivars, there was only difference in D400, with BRS 8990 RR showing a maximum height of $83.3 \mathrm{~cm}, 21 \%$ higher than BRS 9090 RR. When evaluated under D350, BRS 8990 RR showed an increase of $13 \%$ in the number of pods compared to BRS 9090 RR. Both cultivars showed linear behavior for the grain yield, increasing according the plant population, with the highest grain yield obtained under the density of 400.000 plants $\mathrm{ha}^{-1}\left(4527.3 \mathrm{~kg} \mathrm{ha}^{-1}\right)$. The weight of 100 grains was not influenced by any variation factor.

Keywords: Glycine max, cultivars, yield

\section{Introduction}

Soybean (Glycine max L.) is one of the main oilseed commodities grown in the world and has great socioeconomic importance for Brazil, which is one of the main producers. Alongside beans and peanuts, soybeans are considered the main crop among leguminosae (Henriques Neto et al., 1998). The chemical composition of soybeans, with high protein content, is one of the reasons for its utilization for human food and agroindustrial application, including agricultural input industries (Mauad et al., 2010).

The highlight of soybeans in brazilian agribusiness is mainly associated with its high productive potential in different regions of the country. Achieving maximum productivity is the main objective in crop planning and it depends, besides the edaphoclimatic conditions, on the various management techniques employed (Cruz et al., 2016).

For Assis et al. (2014), among the practices adopted to obtain higher productivity, the choice of planting density and the best arrangement between plants are highlighted as potential tools. Tourino et al. (2002), also highlight the plant population per linear meter as one of the factors that most influence productivity, because competition of plants for water, nutrients and light may occur in function of the chosen density.

Thus, studies have shown the importance of knowing the ideal planting density (Peixoto et al., 2002 Mauad et al., 2010; Assis et al., 2014; Cruz et al., 2016) and cultivar (Perini et al., 2012) for a given region whose characteristics have an effect on crop performance. The aim was to evaluate the influence of soybean planting density and cultivar on yield components in the Amazon southeast.

\section{Materials and Methods}

\subsection{Description of the Study Location}

The study was conducted from February to August of 2015 in the experimental area of Embrapa Eastern Amazon, Paragominas city ( $02^{\circ} 59$ ' $45^{\prime \prime} \mathrm{S}$ and $\left.47^{\circ} 21^{\prime} 10^{\prime \prime} \mathrm{W}\right)$. The climate region is tropical rainy (Aw, according to the Köppen classification), with a rainy season beginning in December, extending until May, and lower water availability between June and November. The average annual precipitation is $1.800 \mathrm{~mm}$, the annual relative humidity is $82 \%$ and the average temperature is $26.3{ }^{\circ} \mathrm{C}$ (Rodrigues et al., 2003). The soil in the experimental area was classified as Oxisol (Embrapa, 2011), whose physical and chemical properties are presented in Table 1. 
Table 1. Physical and chemical properties in the $0.2 \mathrm{~m}$ deth of the soil at the study área

\begin{tabular}{|c|c|c|c|c|c|c|c|c|c|c|c|}
\hline $\mathrm{pH}$ & Total P & $\mathrm{K}$ & $\mathrm{Ca}$ & $\mathrm{Ca}+\mathrm{Mg}$ & $\mathrm{Al}$ & $\mathrm{H}+\mathrm{Al}$ & CEC & V & Sand & Silt & Clay \\
\hline $\mathrm{H}_{2} \mathrm{O}$ & $\mathrm{mg} \mathrm{dm}^{-3}$ & & \multicolumn{5}{|c|}{$\mathrm{cmol}_{\mathrm{c}} \mathrm{dm}^{-3}$} & $\%$ & $\mathrm{~g} \mathrm{~kg}^{-1}$ & & \\
\hline 5.5 & 2 & 31 & 3.6 & 5.2 & 0.1 & 4.8 & 4.8 & 47 & 34 & 286 & 680 \\
\hline
\end{tabular}

\subsection{Treatments and Experimental Design}

The study design was a $2 \times 4$ factorial in randomized blocks. The treatments consisted of two soybean cultivars (BRS 9090 RR and BRS 8990 RR) and four planting densities, with three replications. The corresponding plant populations were $250.000,300.000,350.000$ and 400.000 plants ha ${ }^{-1}$ for the densities of $13,15,18$ and 20 plants $\mathrm{m}^{-1}$.

The area had been made up of four lines of $5.0 \mathrm{~m}$ in length, spaced $0.5 \mathrm{~m}$ between the lines. Two useful plant lines were used to evaluate grain yield at harvest, discounting $0.5 \mathrm{~m}$ from each extremity, and the others were used for other evaluations or constituting the borders.

\subsection{Field Planting and Maintenance}

All plots received liming (300 $\mathrm{kg} \mathrm{ha}^{-1}$ dolomitic limestone under haul), $100 \mathrm{~kg} \mathrm{ha}^{-1}$ of $\mathrm{P}_{2} \mathrm{O}_{5}$ and $50 \mathrm{~kg} \mathrm{ha}^{-1}$ of $\mathrm{K}_{2} \mathrm{O}$ at sowing, mixed and distributed in the furrow. The sources used were monoammonium phosphate (MAP) and potassium chloride, respectively. In addition, maintenance fertilization with $172 \mathrm{~kg} \mathrm{ha}^{-1}$ of MAP and $150 \mathrm{~kg} \mathrm{ha}^{-1}$ of potassium chloride $(\mathrm{KCl})$ was performed in the planting line. At the time of planting, seeds were inoculated with Bradyrhizobium japonicum strains, in order to obtain a good nodulation of the plant roots, ensuring nitrogen supply to the crop.

The seeds were treated with $200 \mathrm{~mL}$ Standak Top fungicide (Piraclostrobin + methyl thiophanate + Fipronil) for $100 \mathrm{~kg}$ of seeds.

\subsection{Data Collection}

Five plants were selected by accessing the two central collection lines for data collection on first strip insertion height $(\mathrm{cm})$, plant height $(\mathrm{cm})$, number of pots per plant, grain yield $(\mathrm{kg}$ $\mathrm{ha}^{-1}$ ) and weight of 100 grains (g). A grain mass was corrected to $13 \%$ humidity.

\subsection{Data Analysis}

Data collected were subjected to analysis of variance (ANOVA) to determine the effects of distinct planting densities of soybean cultivars, as well as the interaction of factors on the measurements. Significant treatment means were compared by Tukey test at $5 \%$ of probability.

\section{Results and Discussion}

The effects of planting density on the yield components of soybean cultivars are presented in Table 2. There was no interaction between cultivars and planting densities on the studied variables, except for the number of pods per plant. Evaluating the cultivars in isolation, it was observed that there was significant effect for plant height and number of pods per plant, while the adoption of different densities did not influence the weight of 100 grains. 


\section{MInstitute Macrothink $_{\text {Int }}$}

Table 2. Means of first pod insertion height $(\mathrm{IH})$, plant height $(\mathrm{H})$, number of pods per plant (NPP), grain yield (Y) and weight of 100 grains (W100) in two soybean cultivars at four planting densities

\begin{tabular}{llllll}
\hline Variation factor & $\begin{array}{l}\mathrm{IH} \\
(\mathrm{cm})\end{array}$ & $\begin{array}{l}\mathrm{H} \\
(\mathrm{cm})\end{array}$ & $\mathrm{NPP}$ & $\begin{array}{l}\mathrm{Y} \\
\mathrm{kg} \mathrm{ha}^{-1}\end{array}$ & $\begin{array}{l}\mathrm{W} 100 \\
\mathrm{~g} \mathrm{~kg}^{-1}\end{array}$ \\
\hline Cultivars $(\mathrm{C})$ & $0.71^{\mathrm{ns}}$ & $4.89^{*}$ & $14.98^{*}$ & $0.11^{\mathrm{ns}}$ & $0.23^{\mathrm{ns}}$ \\
Density (D) & $16.33^{*}$ & $10.04^{*}$ & $9.87^{*}$ & $29.89^{*}$ & $1.03^{\mathrm{ns}}$ \\
C x D & $1.09^{\mathrm{ns}}$ & $3.00^{\mathrm{ns}}$ & $4.04^{*}$ & $1.52^{\mathrm{ns}}$ & $1.67^{\mathrm{ns}}$ \\
\hline CV $(\%)$ & 9.38 & 9.14 & 15.20 & 6.79 & 9.17 \\
\hline
\end{tabular}

$\mathrm{ns}=$ not significant $*$ = significant at $5 \%$ probability to $\mathrm{F}$ test.

The height of insertion of the first pod showed a tendency of increase with the increment of plants per linear meter for cultivar BRS 8990 RR, not the same behavior for cultivar BRS 9090 RR, which only showed difference when the density of 300.000 plants $\mathrm{ha}^{-1}$ was used of the other treatments (Table 3). For BRS 8990 RR, there was an increase of up to $36 \%$ in height when compared to lower (D250) and higher densities (D350 and D400). The study of this variable is fundamental for the definition of plant suitability for mechanized grain harvesting (Medina, 1994). For Sediyama et al. (1999), the ideal range of height is between 10 and $12 \mathrm{~cm}$. Queiroz et al. (1981) considers that this height must be at least $13 \mathrm{~cm}$ in order to reduce losses during harvest.

For plant height, among soybean cultivars, there was only difference in D400, with BRS 8990 RR showing a maximum height of $83.3 \mathrm{~cm}, 21 \%$ higher than BRS $9090 \mathrm{RR}(68.7 \mathrm{~cm})$ (Table 3). BRS 9090 RR showed no difference in relation to the planting density. On the other hand, cultivar BRS 8990 RR showed linear growth as planting density increased, reaching a higher height when the plant population per hectare was 400.000 . The higher growth of plants subjected to higher planting density may be associated with the increased intraspecific competition that this environment provides, mainly by light, resulting in blunt plants (Mauad et al., 2010; Cruz et al., 2016).

Table 3. Average values of first pod insertion height in plants of two soybean cultivars, at four planting densities

\begin{tabular}{|c|c|c|c|}
\hline \multirow[b]{2}{*}{ Density (plants ha ${ }^{-1}$ ) } & \multicolumn{3}{|c|}{ BRS $8990 \mathrm{RR}$} \\
\hline & \multicolumn{2}{|c|}{ First pod insertion height $(\mathrm{cm})$} & Mean \\
\hline D250 & $12.0 \mathrm{Aba}$ & $11.0 \mathrm{Ba}$ & $11.5 \mathrm{~B}$ \\
\hline D300 & $10.7 \mathrm{Ba}$ & $11.0 \mathrm{Ba}$ & $10.8 \mathrm{~B}$ \\
\hline D350 & $14.0 \mathrm{Aa}$ & $15.3 \mathrm{Aa}$ & $14.7 \mathrm{~A}$ \\
\hline D400 & $14.0 \mathrm{Aa}$ & $15.0 \mathrm{Aa}$ & $14.5 \mathrm{~A}$ \\
\hline \multirow[t]{2}{*}{ Mean } & $12.7 \mathrm{a}$ & $13.1 \mathrm{a}$ & 12.9 \\
\hline & \multicolumn{2}{|c|}{ Plant height $(\mathrm{cm})$} & Mean \\
\hline D250 & $62.7 \mathrm{Aa}$ & $57.0 \mathrm{Ba}$ & $59.8 \mathrm{~B}$ \\
\hline D300 & $58.3 \mathrm{Aa}$ & $64.3 \mathrm{Ba}$ & $61.3 \mathrm{~B}$ \\
\hline D350 & $58.0 \mathrm{Aa}$ & $64.3 \mathrm{Ba}$ & $61.2 \mathrm{~B}$ \\
\hline D400 & $68.7 \mathrm{Ab}$ & $83.3 \mathrm{Aa}$ & $76.0 \mathrm{~A}$ \\
\hline Mean & $61.9 \mathrm{~b}$ & $67.3 \mathrm{a}$ & 64.6 \\
\hline
\end{tabular}

Means followed by the same uppercase letter in the column and lowercase in the row do not differ from each other by the Tukey test at $5 \%$ probability. 


\section{Macrothink}

The variations observed in the number of pods per plant showed that, while the cultivar BRS 9090 RR, guaranteed superior number of pods (92.7) under D350, BRS 8990 RR had better performance for this variable under D350 and D400 (Table 4). When evaluated under D350, BRS 8990 RR showed a $13 \%$ of increase in the number of pods compared to BRS 9090 RR. Both cultivars showed a tendency to increase the number of pods with increasing density up to 350.000 plants ha ${ }^{-1}$, with smaller variation of BRS 8990 RR between D350 and D400. The number of pods per plant is one of the main components of soybean production (Vernetti, 1983). However, this component, when evaluated in isolation, is not sufficient to ensure the yield potential of the crop, as it still depends on the ability of the plant to fill the pods with grains (Peixoto et al., 2002).

Table 4. Average values of number of pods per plant in two soybean cultivars, cultivated in four planting densities

\begin{tabular}{llcccc}
\hline \multirow{2}{*}{ Cultivars } & \multicolumn{5}{l}{ Density $\left(\right.$ plants ha $\left.^{-1}\right)$} \\
\cline { 2 - 6 } BRS 9090 RR & D250 & D300 & D350 & D400 & Mean \\
\hline BRS 8990 RR & $77 \mathrm{Ab}$ & $72 \mathrm{Ab}$ & $104 \mathrm{Aa}$ & $103 \mathrm{Aa}$ & $89 \mathrm{~A}$ \\
Mean & $61.5 \mathrm{c}$ & $74.5 \mathrm{bc}$ & $98.3 \mathrm{a}$ & $83.5 \mathrm{ab}$ & 79.5 \\
\hline
\end{tabular}

Means followed by the same uppercase letter in the column and lowercase in the row do not differ from each other by the Tukey test at $5 \%$ probability.

The cultivars studied under the four densities presented satisfactory yields, ranging from 3.262 to $4.726 \mathrm{~kg} \mathrm{ha}^{-1}$ (Table 5). Both cultivars showed linear behavior as the plant population increased, with the highest grain yield obtained under the density of 400.000 plants $\mathrm{ha}^{-1}$ (or 20 plants $\mathrm{m}^{-1}$ ), with an average of $4527.3 \mathrm{~kg} \mathrm{ha}^{-1}$. There was no difference between cultivars, regardless of the density used. Cruz et al. (2016), when evaluating soybean yield in density of up to 22 plants $\mathrm{m}^{-1}$ also registered linear behavior for this variable. 
Table 5. Grain yield $\left(\mathrm{kg} \mathrm{ha}^{-1}\right)$ and weight of 100 grains (g) in two soybean cultivars under four planting density

\begin{tabular}{llll}
\hline $\begin{array}{l}\text { Density } \\
\text { (plants ha-1) }\end{array}$ & \multicolumn{2}{l}{ Cultivars } & Mean \\
\cline { 2 - 3 } Grain yield $\left(\mathrm{kg} \mathrm{ha}^{-1}\right)$ & BRS 9090 & $3284.66 \mathrm{C}$ \\
D250 & $3262.98 \mathrm{Ca}$ & $3306.47 \mathrm{Ca}$ & $3421.33 \mathrm{C}$ \\
D300 & $3518.63 \mathrm{BCa}$ & $3323.76 \mathrm{Ca}$ & $4067.00 \mathrm{~B}$ \\
D350 & $4119.88 \mathrm{Aba}$ & $4013.79 \mathrm{Ba}$ & $4527.33 \mathrm{~A}$ \\
D400 & $4327.49 \mathrm{Aa}$ & $4726.63 \mathrm{Aa}$ & 3894.25 \\
Mean & $3837.33 \mathrm{a}$ & $3842.83 \mathrm{a}$ & Mean \\
& Weight of 100 grains $(\mathrm{g})$ & $13.00 \mathrm{~A}$ \\
D250 & $13.93 \mathrm{Aa}$ & $12.07 \mathrm{Aa}$ & $12.23 \mathrm{~A}$ \\
D300 & $12.27 \mathrm{Aa}$ & $12.20 \mathrm{Aa}$ & $12.02 \mathrm{~A}$ \\
D350 & $12.03 \mathrm{Aa}$ & $12.00 \mathrm{Aa}$ & $12.87 \mathrm{~A}$ \\
D400 & $12.33 \mathrm{Aa}$ & $13.40 \mathrm{Aa}$ & 12.53 \\
Mean & $12.64 \mathrm{a}$ & $12.42 \mathrm{a}$ & 3 \\
\hline
\end{tabular}

Means followed by the same uppercase letter in the column and lowercase in the row do not differ from each other by the Tukey test at $5 \%$ probability.

The weight of 100 grains was not influenced by any variation factor in this study, even if changes are expected mainly due to the cultivars, since this genetic trait has high heritability (Table 5).

\section{Conclusion}

At higher densities (D350 and D400), soybean plants showed higher yield, except for the 100 grain mass that was not influenced by any of the factors studied. BRS 8990 RR showed better performance under amazon edaphoclimatic conditions.

\section{References}

Assis, T. R., Zineli, V. P, Silva, R. E., Costa, W. C. A., \& Olivato, I. (2014). Arranjo espacial de plantas na cultura da soja. Circular Técnica. Instituto de ciências da saúde, agrárias e humanas (ISAH) - Araxá - MG, Maio de 2014.

Cruz, S. C. S., Sena-Junior, D. G., Santos, D. M. A., Lunezzo, L. O., \& Machado, C. G. (2016). Cultivo de soja sob diferentes densidades de semeadura e arranjos espaciais. Revista de Agricultura Neotropical, 1-6. https://doi.org/10.32404/rean.v3i1.431

Empresa Brasileira de Pesquisa Agropecuária - EMBRAPA (2011). Manual de análises químicas de solos, plantas e fertilizantes (2nd ed.). Brasília, DF: Embrapa. p. 627.

Henriques Neto, D. H., Tavora, F. J. A. F., Silva, F. P., Santos, M. A., \& Melo, F. I. O. (1998). 
Componentes de produção e produtividade do amendoim submetido a diferentes populações e configurações de plantio. Revista Brasileira de Oleaginosas e Fibrosas, 2, 113-122.

Mauad, M., Silva, T. L. B., Almeida Neto, A. I., \& Abreu, V. G. (2010). Influência da densidade de semeadura sobre características agronômicas na cultura da soja. Revista Agrarian, Dourados-MS., 3(9), 175-181. ISSN: 1984-2538.

Medina, P. F. (1994). Produção de sementes de cultivares precoces de soja, em diferentes épocas e locais do Estado de São Paulo. 1994. 173f. Thesis (Doutorado em Agronomia/ Fitotecnia) - Escola Superior de Agricultura "Luiz de Queiroz", Universidade de São Paulo, Piracicaba.

Peixoto, C. P., Camara, G. M. S., Martins, M. C., \& Marchiori, L. F. S. (2002). Efeitos de épocas de semeadura e densidade de plantas sobre a produtividade de cultivares de soja no Estado de São Paulo. Revista de Agricultura, 77(2), 265-291. https://doi.org/10.1590/S0103-90162000000100015

Perini, L. J., Fonseca Júnior, N. S, Destro, D., \& Prete, C. E. C. (2012). Componentes da produção em cultivares de soja com crescimento determinado e indeterminado. Semina: CiênciasAgrárias, 33(1), 2531-2544. https://doi.org/10.1590/S0103-90162000000100015

Queiroz, E. F., Neumaier, N., Torres, E., Pereira, L. A. G., Bianchetti, A., Terazawa, F., ... Yamashita, J. (1981). Recomendações técnicas para a colheita mecânica. In S. Miyasaka, J.C. Medina, (Eds.). A soja no Brasil (pp.701-10). Campinas: ITAL.

Rodrigues, T. E., Silva, R. C., Silva, J. M. L., Oliveira, R. C., Jr., Gama, J. R. N. F., \& Valente, M. A. (2003). Caracterização e classificação dos solos do município de Paragominas, estado do Pará. Belém: Embrapa Amazônia Oriental. p. 51.

Sediyama, T., Teixeira, R. C., \& Reis, M. S. (1999). Melhoramento da soja. In A., Borém (Ed). Melhoramento de espécies cultivadas (pp. 478-533) Viçosa (Minas Gerais): Universidade Federal de Viçosa.

Tourino, C. C. M., Rezende, M. P. E., \& Salvador, N. (2002). Espaçamento, densidade e uniformidade de semeadura na produtividade e características agronômicas da soja. Pesquisa $\begin{array}{lll}\text { Agropecuária } \quad \text { Brasileira, } & \text { 37(8), } & \text { 1071-1077. }\end{array}$ https://doi.org/10.1590/S0100-204X2002000800004

Vernetti, F. J. (1983). Genética da soja: caracteres qualitativos. In F.J. Vernetti, (Ed.), Soja: genética e melhoramento (pp. 93-124). Campinas: Fundação Cargill.

\section{Copyright Disclaimer}

Copyright for this article is retained by the author(s), with first publication rights granted to the journal.

This is an open-access article distributed under the terms and conditions of the Creative Commons Attribution license (http://creativecommons.org/licenses/by/4.0/). 